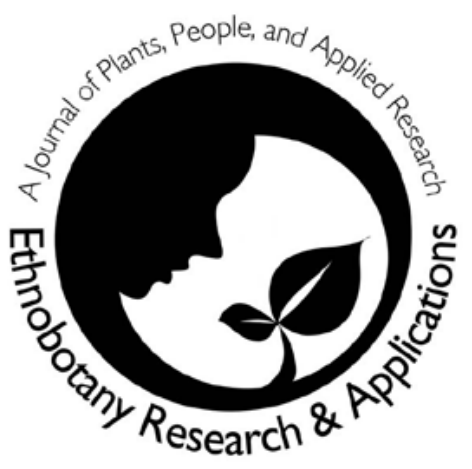

\section{Ethnobotanical Assessment of Moringa oleifera Lam. in Southern Benin (West Africa)}

\author{
Eric E. Agoyi, Achille E. Assogbadjo, Gerard \\ Gouwakinnou, Farris A.Y. Okou, and Brice Sinsin
}

\section{Research}

\begin{abstract}
For decades, plant species, particularly those used as non-tree forest products (NTFPs), have been known to play an important role in the livelihood of local populations, particularly in rural Africa. The present study investigated the uses of various parts of Moringa oleifera Lam. in southern Benin. It aimed at capturing indigenous knowledge on the uses of $M$. oleifera as a preliminary step toward future efforts to devise better management options of this plant species. An ethnobotanical survey was carried out in southern Benin (Guineo-Congolese zone) with a sample of 439 informants (201 women and 238 men) belonging to Fon, Waci, Xwla, Sahouè, Djerma, Kotafon, Aïzo, Goun, and Yoruba socio-cultural groups. It was found that $M$. oleifera is known in South Benin under different local names depending on the socio-cultural group. Leaves were the most used part followed by roots, bark, seeds, and pods. Leaves are eaten as a vegetable and also used for medicinal purposes. They are consumed fresh or dried and reduced to powder. Different parts of M. oleifera are used to treat up to 34 diseases according to the local populations. Leaves are also used as fodder for pigs, sheep, and rabbits. The seeds are used to carry out rites for blessing and attracting customers. The study showed that $M$. oleifera plays an important role in rural areas of South Benin where it is used as a nutritional and medicinal plant. Local populations could benefit by further adoption of the species in agroforestry systems.
\end{abstract}

\section{Resume}

Depuis des décennies, les espèces végétales, particulièrement celles utilisées comme produits forestiers non ligneux (PFNLs) sont connues pour le rôle important qu'elles jouent dans la vie des populations locales. La présente étude a porté sur les utilisations faites des différentes parties de Moringa oleifera Lam. au Sud-Bénin. L'objectif de l'étude était de capitaliser les connaissances endogènes sur les utilisations de $M$. oleifera au Bénin afin de contribuer à une meilleure gestion de cette ressource. Il a été effectué une enquête ethnobotanique au Sud du Bénin (Zone Guinéo Congolaise) auprès d'un échantillon de 439 personnes (201 femmes et 238 hommes) appartenant aux ethnies Fon, Waci, Xwla, Sahouè, Djerma, Kotafon, Aïzo, Goun, Yoruba. L'enquête ethnobotanique a montré que $M$. oleifera est connu sous différentes appellations locales en fonction des groupes socio-culturels présents dans le sud Bénin. Les feuilles sont les organes les plus utilisés suivies des racines, l'écorce, les graines et gousses. Les feuilles sont utilisées fraîches comme légume-feuilles ou séchées et réduites en poudre. L'étude révèle que $M$. oleifera est utilisé dans le traitement de trente-quatre maladies selon les populations locales. Les feuilles sont aussi utilisées comme aliment dans l'élevage du porc, du lapin et de la volaille. Les graines sont utilisées pour faire des ri-

\section{Correspondence}

Eric E. Agoyi , Kampala, UGANDA. ericagoyi@yahoo.fr Achille E. Assogbadjo, University of Abomey-Calavi, 01 BP 526, Cotonou, BENIN. assogbadjo@yahoo.fr

Gerard Gouwakinnou, University of Abomey-Calavi, 01 BP 526, Cotonou, BENIN. gougerano@yahoo.fr

Farris A.Y. Okou, c.o Christophe Okou, 01 PO Box, 357 Porto-Novo, BENIN. farrisy@yahoo.fr

Brice Sinsin, University of Abomey-Calavi, 01 BP 526, Cotonou, BENIN. bsinsin@gmail.com

Ethnobotany Research \& Applications 12:551-560 (2014)

Published: 24 November 2014 
tuels dans le but d'attirer la clientèle ou le sexe opposé. Moringa oleifera joue un rôle très important pour les populations rurales du Sud-Bénin, surtout au plan nutritionnel et médicinal. Les populations locales devraient donc opter pour son intégration dans les systèmes agroforêstiers.

\section{Background}

Numerous studies have shown the importance of nontree forest products (NTFPs) in the livelihood of local populations, particularly in rural Africa, both for their nutritional and income security (Aubé 1996, Dethier 1998, Kouyaté 2005, Sunderland et al. 2000). In Benin, NTFPs are known for their multipurpose uses including nutrition, animal feed, medicine, and being sources of income. Although NTFPs contribute to household incomes and to economic development, the quantitative assessment of the products used have never been studied exhaustively; only the products which are subject of export were studied, such as Vitellaria paradoxa C.F.Gaertn. (Agbahungba \& Depommier 1989), Adansonia digitata L. (Assogbadjo et al. 2005a,b,c, 2006, 2008, Codjia \& Assogbadjo 2001, Codjia et al. 2003), Jatropha curcas L. and other edible trees (Assogbadjo et al. 2009, 2012), Parkia biglobosa (Jacq.) G.Don (Agbahungba \& Depommier 1989), and the edible mushrooms (Yorou \& De Kersel 2000). The increase in demand and the trade of NTFPs poses a problem for sustainability of the existing resources (Kimba 2010 , Verdcourt 1985). This problem would be more easily solved if such resources are assessed and new production systems developed, hence the need for the assessment and valuation of plant resources.

Among NTFPs, moringa (Moringa oleifera Lam.) is a multipurpose tree introduced into Africa and now very widespread. It is used by rural populations for nutrition, medicinal purposes, and as hedges for house and farm demarcation. Recently, $M$. oleifera has gained interest especially because of its nutritional and medicinal value. Indeed, in several African countries such as Sudan, Tanzania, Niger, Senegal, Nigeria, Ghana, and Burkina Faso, leaves and seeds of $M$. oleifera are considered as important sources of proteins, lipids, vitamins, and essential minerals for human health (Afuang et al. 2003, Leonard 2006, Oliveira et al. 1999, Sreelatha \& Padma 2009). Although M. oleifera is integrated into several programs of food assistance for preventing malnutrition of children and nursing mothers (Afuang et al. 2003, Leonard 2006, Sreelatha \& Padma 2009), a lack of information still persists for this species, notably concerning local knowledge of uses. Kumar et al. (2007) showed that the seeds of $M$. oleifera have antioxidant properties and thus possess possible anticancer potential. Antispasmodic activity and hypotensive components of $M$. oleifera provide a scientific basis for the plant's traditional uses in the management of gastro-intestinal motility disorders (Gilani et al. 1994). Kalogo et al. (2000) also indicated that antibacterial properties of $M$. oleifera make it a useful medicinal plant.

In assessing the inhibition potential of combined extracts of $J$. curcas and $M$. oleifera on saprophytes and fungal contaminants, Ayanbimpe et al. (2009) concluded that these easily accessible, cheap extracts could be substitutes for antibiotics and antifungals frequently used in laboratories such as chloramphenicol and cycloheximide. However, in spite of these authors' interest in nutritional and medicinal aspects of $M$. oleifera, their work did not address traditional methods of use, manufacture of remedies, or dosages. The introduction of fresh leaves of $M$. oleifera in Nile tilapia [Oreochromis niloticus (Linnaeus 1758)] dishes is also known to cause a substantial drop in the cholesterol rate in plasma and muscles (Afuang et al. 2003), but no study informs about its uses in the breeding of poultry, pigs, rabbits, etc.

Studies on $M$. oleifera in Benin are limited to an unpublished work (Kogblevi 1983) regarding adaptation of $M$. oleifera in dry areas, its nitrogen, phosphorous, and potassium content. This study aimed at filling this gap through documenting the indigenous knowledge on $M$. oleifera in southern Benin.

\section{Methods}

\section{Study area}

The study took place in southern Benin between $6^{\circ} 25$ ' and $7^{\circ} 30^{\prime} \mathrm{N}$ in the Guineo-Congolese zone. In Benin the Guineo-Congolese area is subdivided into four phyto-districts which are: Plateau, Coast, Ouémé, and Pobè (Figure 1). The pluviometry is bimodal with an annual average of $1200 \mathrm{~mm}$. The annual average temperature ranges between 25 and $29^{\circ} \mathrm{C}$ and the relative humidity between 69 and $97 \%$. The climate is subequatorial, characterized by four more or less marked seasons. The main ethnic groups are Fon (and other assimilated groups), Adja (and assimilated groups), and Yoruba (Floquet \& Van den Akker 2000).

\section{Data collection}

Data were collected through interviews with individuals and groups of individuals chosen at 11 townships. The localities were rationally chosen using three criteria: the presence of the species (the species was considered as present where it was met in 10 different places within a locality), the existence of a market in which its products are commercialized, and the main ethnic groups. The choice of the surveyed persons was at random, the sample size determined using the normal approximation of binomial distribution (Dagnelie 1998):

$$
n=U_{1-\alpha / 2}^{2} \times P(1-P) / d^{2}
$$




\section{Agoyi et al. - Ethnobotanical Assessment of Moringa oleifera Lam. in Southern Benin (West Africa)}

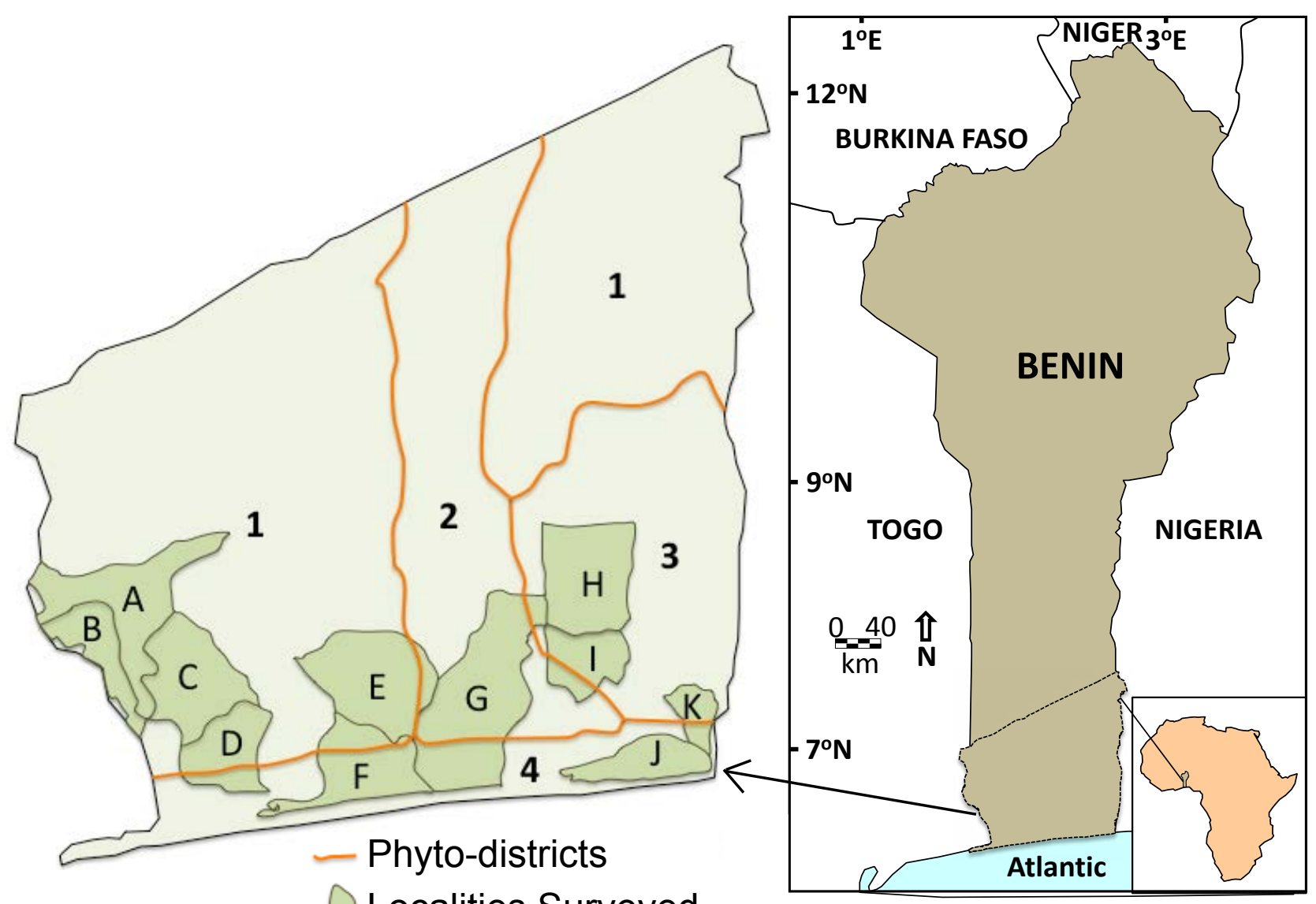

Figure 1. The study area in South Benin surveyed for ethnobotanical uses of Moringa oleifera Lam. Phyto-districts: 1) Plateau, 2) Ouémé, 3) Pobè, and 4) Coast. Guinea-Congolese Zone townships: A) Lokossa, B) Athiémè, C) Houéyogbé, D) Comé, E) Tori-Bossito, F) Ouidah, G) Abomay-Calavi, H) Adjohoun, I) Dangbo, J) Adjarra, and K) Sèmè-Kpodji.

Where $\mathrm{n}$ is the size of the sample and $\mathrm{P}$ is the proportion of informants who know and use the species. To compute the size of the sample, a brief pre-survey of 100 persons per locality was carried out. The pre-surveyed persons had to say whether they have used, at least once, a product of $M$. oleifera. Only the proportion of positive answers was considered. $U_{1-\alpha / 2}$ is the value of the normal random variable where, for a probability value of $1-\alpha / 2, U^{2} \approx 1.96$ with $\alpha=0.05$. A $5 \%$ margin of error (d) was considered.

On this basis a total of 439 persons were interviewed, of which 201 were women and 238 were men. Individual semi-structured interviews were used to collect data from the sampled participants. However, some focus group discussions were also done to check the reliability of the information gathered during the individual interviews. The discussion groups were often composed of 5 to 7 individuals.

\section{Data analysis}

Data were encoded after counting survey forms. Frequencies were attributed to the various organs used for medicine purposes to assess their contribution. The consensus value of use-manner (CMU) was expressed for the medicinal uses by the formula $\mathrm{CMU}=M x / M t$ (Byg \& Baslev 2001). Where $M x$ is the number of people who quote a use-manner (recipe) for a given sickness and $M t$ is the total number of people who quoted any use-manner for this sickness. The $\mathrm{CMU}$ ranges between 0 and 1 to measure the degree of consensus on each recipe in traditional medicine and then can be used to assess the relative efficacy of each recipe, assuming that the more a recipe is commonly quoted, the more effective it is. 
Table 1. Local names for Moringa oleifera Lam. in South Benin, West Africa.

\begin{tabular}{|l|l|l|}
\hline Ethnicities & Local names & Literal translations \\
\hline Aïzo & Kpatima ou kpatovigbé & Leaves of demarcation plants \\
\hline Djerma & Sibkaali ou Zogala & Undetermined \\
\hline Fon & Kpatimawiniwini & Demarcation plants with small leaves \\
\hline Goun & Amaflinflin ou Kpatimaflinflin & Small leaves or demarcation plants with small leaves \\
\hline Kotafon & Kpatoma ou kpaounbovi & Fencing tree \\
\hline Sahouè & Kpatama & Fencing tree \\
\hline Waci & Yovovigbé, yovovitin, kpatovigbé & $\begin{array}{l}\text { Small leaves of demarcation plants for yovo (white } \\
\text { people) }\end{array}$ \\
\hline Xwla & Kutin ou amawiniwini & Plant with very small leaves \\
\hline Yoruba & Ewé ilé & House tree \\
\hline
\end{tabular}

\section{Results}

Moringa oleifera is known under different local names (Table 1) depending on the socio-cultural group. These local names are generally derived from either the small size of leaves, its use as a demarcation plant, or the foreign origin.

\section{Moringa oleifera common uses}

It was observed that the leaf is the most-used organ followed by the root, bark, seeds, and pods. The rural communities use the leaves as a vegetable and other meals or for medicinal purposes. The species is planted in gardens as a vegetable plant or in quickset hedges to delimit plots of land and houses or in plantations by those who market the leaves fresh or in the form of powder.

\section{Consuming and processing Moringa oleifera leaves}

Leaves are prepared for nutritional use according to two methods: leaves are consumed fresh as a vegetable or dried and reduced into powder. In the latter case it serves as nutritional powder recommended for children, pregnant women and nursing mothers, persons living with HIVI AIDS, or aging persons experiencing a nutritional deficit. The procedure of processing the leaves of $M$. oleifera is shown in Figure 2.

\section{Medicinal uses of Moringa oleifera}

Surveys revealed that $M$. oleifera is used to treat up to 34 diseases according to the local populations. Different parts of the $M$. oleifera tree are used for this purpose; leaves are the most used followed by roots and bark, with pods and seeds less utilized (Figure 3 ).

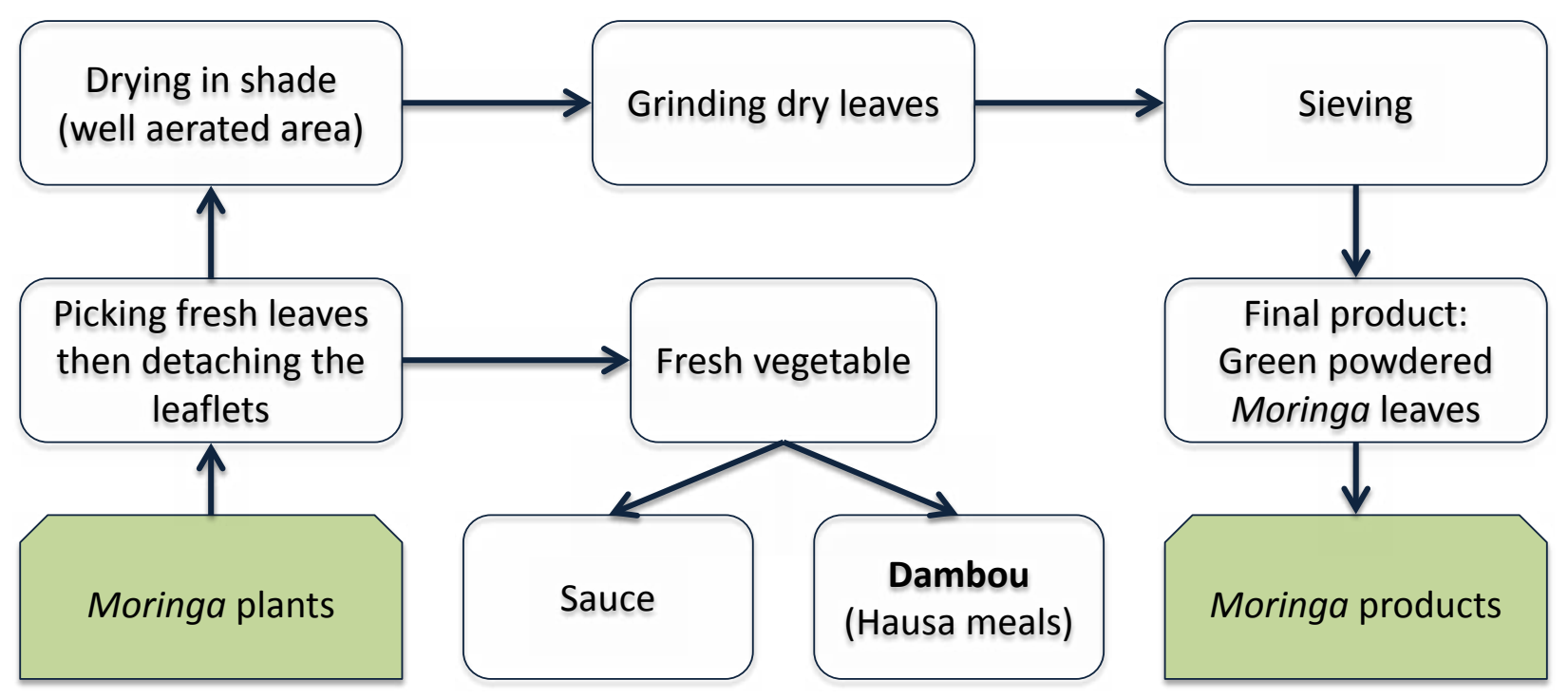

Figure 2. Processing of Moringa oleifera Lam. leaves in South Benin. Source: Ethnobotanical inquiries. 


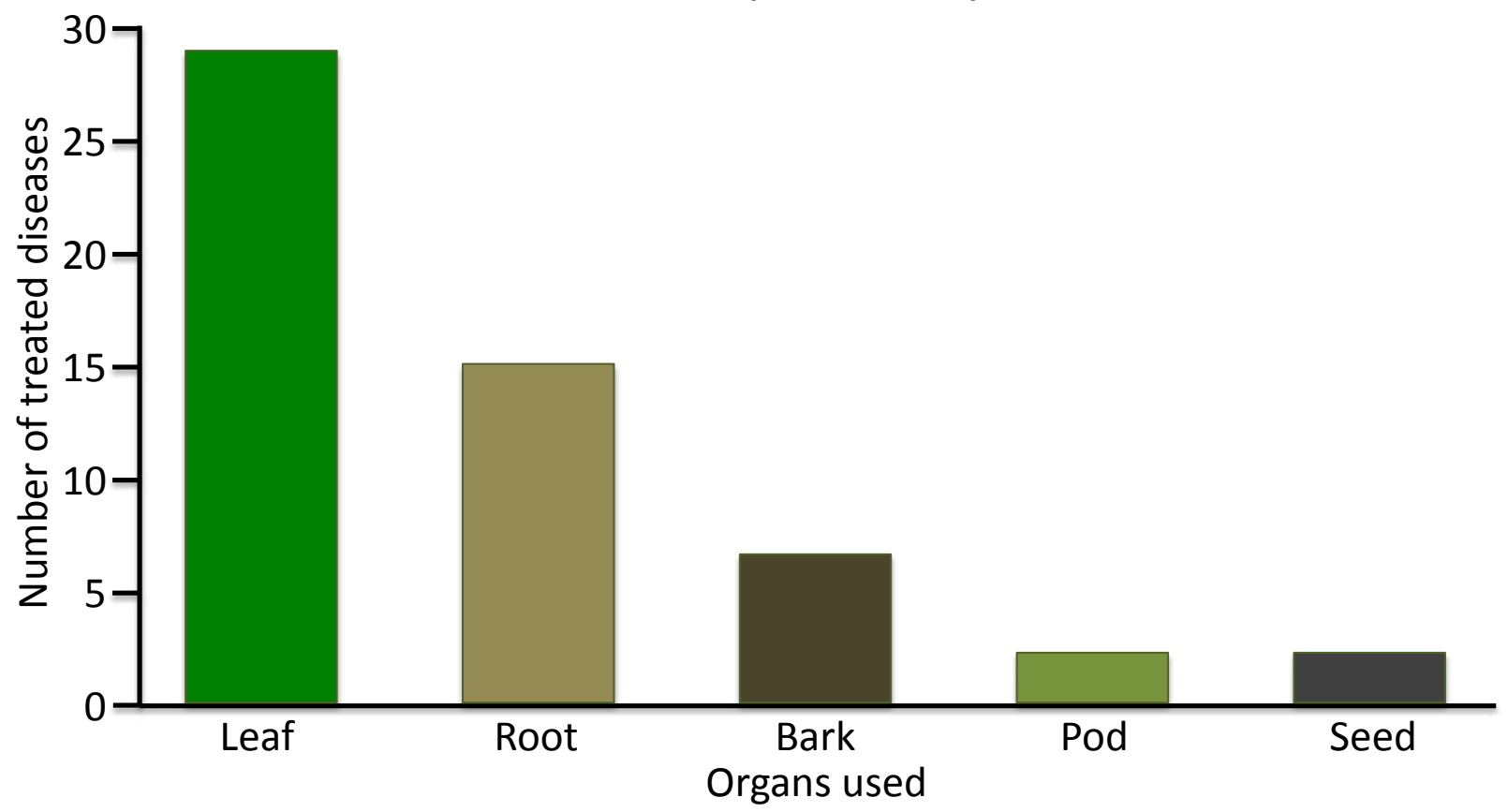

Figure 2. Contribution of Moringa oleifera Lam. organs in treatment of different illnesses in South Benin.

The choice of plant part depends on the disease to be treated, the mode of administration, and the additive chosen. Several recipes were recorded for the 34 illnesses, with a high consensus value of certain recipes showing the relative efficacy of those more commonly known and used among the populations. The manufacturing process- es, the guidelines for use, and the consensus values are summarized in Table 2.

\section{Other uses of Moringa oleifera}

After processing (as outlined in Figure 2), the fresh leaf can also be fed to mammals such as pigs, rabbits, and

Table 2. Therapeutic uses of Moringa oleifera Lam. organs in South Benin. CMU = consensus value of use-manner (values range $0-1$ ).

\begin{tabular}{|c|c|c|c|}
\hline \multicolumn{4}{|l|}{ Parts used } \\
\hline $\begin{array}{l}\text { Illnesses } \\
\text { treated }\end{array}$ & Recipes & Guidelines for use & CMU \\
\hline \multicolumn{4}{|l|}{ Leaves } \\
\hline Abscess & Ground leaf + potassium hydroxide & Apply on the abscess until well & 1 \\
\hline Asthenia & Powder of leaves & Put in the meals (not very hot) in case of attack & 1 \\
\hline Cough & $\begin{array}{l}\text { Infusion of leaves }+ \text { leaves of } \\
\text { Newbouldia laevis (P.Beauv.) Seem. } \\
+ \text { lemon }\end{array}$ & Drink regularly & 1 \\
\hline $\begin{array}{l}\text { Gonorrhea } \\
\text { oligospermia }\end{array}$ & $\begin{array}{l}\text { Fresh leaves }+7 \text { small hot peppers } \\
+ \text { salt }+ \text { wine combined in a bottle }\end{array}$ & $\begin{array}{l}\text { Drink one small glass of the potion in the morning } \\
\text { and evening until } 15 \text { days after recovery }\end{array}$ & 1 \\
\hline Hemorrhoids & Powder of leaves & Put in the meals (not very hot) regularly & 1 \\
\hline Hernia & $\begin{array}{l}\text { Root cut in small pieces + root of } \\
\text { Carica papaya L. + slices of orange } \\
+ \text { seed of Xylopia aethiopica (Dunal) } \\
\text { A.Rich. + white onion + seed of } \\
\text { Monodora myristica (Gaertn.) Dunal } \\
\text { (calabash nutmeg) + water }\end{array}$ & Drink 3 glasses/day for 30-45 days & 1 \\
\hline $\begin{array}{l}\text { High blood } \\
\text { pressure }\end{array}$ & Powder of leaves & Put in the meals (not very hot) at will & 1 \\
\hline
\end{tabular}




\begin{tabular}{|c|c|c|c|}
\hline \multicolumn{4}{|l|}{ Parts used } \\
\hline $\begin{array}{l}\text { Illnesses } \\
\text { treated }\end{array}$ & Recipes & Guidelines for use & CMU \\
\hline \multirow{2}{*}{$\begin{array}{l}\text { Immune } \\
\text { deficiency } \\
\text { caused by } \\
\text { the HIV }\end{array}$} & Powder of leaves & Put in the meals (not very hot) regularly & 1 \\
\hline & Fresh leaves & Eat regularly as vegetable & 1 \\
\hline Infection & $\begin{array}{l}\text { Dried leaves or powder of leaves }+ \\
\text { alcohol }\end{array}$ & $\begin{array}{l}\text { Drink } 3 \text { small glasses/day in the morning, } \\
\text { afternoon, and evening for } 7-10 \text { days }\end{array}$ & 1 \\
\hline Infertility & Powder of leaves & Put in the meals (not very hot) until the conception & 1 \\
\hline Intestinal worms & Powder of leaves & $\begin{array}{l}\text { Put in the meals (not very hot) every day for } 7 \\
\text { days }\end{array}$ & 1 \\
\hline Varicella & $\begin{array}{l}\text { Grind leaves and press out the juice } \\
+ \text { palm oil }\end{array}$ & $\begin{array}{l}\text { Pass on the body of the sick child until totally } \\
\text { healed }\end{array}$ & 1 \\
\hline \multirow[t]{2}{*}{ Fever } & Grind, boil, or soak leaves in water & Bathe with the potion & 1 \\
\hline & $\begin{array}{l}\text { Grind fresh, carefully washed } \\
\text { leaves; press out the juice }\end{array}$ & Drink 3 teaspoons/day of juice until recovered & 0.05 \\
\hline \multirow[t]{2}{*}{$\begin{array}{l}\text { Eyesight } \\
\text { problems }\end{array}$} & $\begin{array}{l}\text { Grind fresh, carefully washed } \\
\text { leaves; press out the juice }\end{array}$ & Put some drops in the eyes & 0.9 \\
\hline & $\begin{array}{l}\text { Leaves }+ \text { roots }+ \text { bark }+ \text { alcohol } \\
\text { combined in a bottle }\end{array}$ & $\begin{array}{l}\text { Drink one small glass of the potion morning and } \\
\text { evening until improved }\end{array}$ & 0.2 \\
\hline Icterus & $\begin{array}{l}\text { Crushed leaves + milk "peak" + } \\
\text { other species leaves }\end{array}$ & Drink the mixture for $10-15$ days & 0.89 \\
\hline Stomach pains & Powder of leaves & Put in the meals (not too hot) for $2-3$ days & 0.83 \\
\hline \multirow[t]{2}{*}{ Malaria } & $\begin{array}{l}\text { Infusion of leaf }+ \text { leaves of Spondias } \\
\text { mombin L. + lemon }\end{array}$ & Drink regularly & 0.78 \\
\hline & Ground leaves + little water & Drink regularly 3 small glasses/day until well & 0.08 \\
\hline $\begin{array}{l}\text { Headaches } \\
\text { and migraine }\end{array}$ & $\begin{array}{l}\text { Grind fresh, carefully washed } \\
\text { leaves; press out the juice }\end{array}$ & $\begin{array}{l}\text { Put some drops in the eyes or massage the } \\
\text { forehead in case of pain }\end{array}$ & 0.77 \\
\hline \multirow[t]{3}{*}{ Typhoid fever } & $\begin{array}{l}\text { Infusion of leaf in association with } \\
\text { other leaves }\end{array}$ & Drink regularly for $7-10$ days & 0.74 \\
\hline & Powder of leaves & Put in the meals (not very hot) until cure & 0.17 \\
\hline & Grind leaves and press out the juice & Drink 3 teaspoons/day until well & 0.22 \\
\hline \multirow[t]{3}{*}{ Anemia } & Crushed leaves + bissap + beer & Drink 3 small glasses/day at will & 0.71 \\
\hline & $\begin{array}{l}\text { Crushed leaves }+ \text { water }+2 \text { lumps } \\
\text { sugar }+ \text { condensed milk }\end{array}$ & Drink 3 small glasses/day at will & 0.65 \\
\hline & Powder of leaves & Put in the meals (not very hot) regularly & 0.16 \\
\hline \multirow[t]{2}{*}{ Indigestion } & Sauce with leaves & Consume at will & 0.67 \\
\hline & Dried leaves + alcohol & Drink at will & 0.29 \\
\hline $\begin{array}{l}\text { Sexual } \\
\text { weakness }\end{array}$ & Powder of leaves & Put in the meals (not very hot) at will & 0.67 \\
\hline \multirow[t]{2}{*}{ Diabetes } & Powder of leaves & Put in the meals (not very hot) in case of attack & 0.55 \\
\hline & Infusion of leaves & Drink regularly & \\
\hline Flu and sinusitis & $\begin{array}{l}\text { Grind fresh, carefully washed } \\
\text { leaves; press out the juice }\end{array}$ & $\begin{array}{l}\text { Put some drops of the juice in nostrils in case of } \\
\text { attack }\end{array}$ & 0.54 \\
\hline Otitis & $\begin{array}{l}\text { Grind fresh, carefully washed } \\
\text { leaves; press out the juice }\end{array}$ & $\begin{array}{l}\text { Put some drops in ears morning evening for } 5-7 \\
\text { days }\end{array}$ & 0.44 \\
\hline
\end{tabular}




\section{Agoyi et al. - Ethnobotanical Assessment of Moringa oleifera Lam. in Southern Benin (West Africa)}

\begin{tabular}{|c|c|c|c|}
\hline \multicolumn{4}{|l|}{ Parts used } \\
\hline $\begin{array}{l}\text { Illnesses } \\
\text { treated }\end{array}$ & Recipes & Guidelines for use & CMU \\
\hline Dysmenorrhea & Powder of leaves & Put in the meals (not very hot) for $30-45$ days & 0.4 \\
\hline \multicolumn{4}{|l|}{ Roots } \\
\hline Articular pains & Crushed root + lemon & Massage the painful joint with the paste until well & 1 \\
\hline Dysentery & $\begin{array}{l}\text { Crush fresh root and press out the } \\
\text { juice }\end{array}$ & Drink 2 teaspoons/day for $5-7$ days & 1 \\
\hline Prostatitis & $\begin{array}{l}\text { Root }+ \text { hot pepper (crushed whole) + } \\
\text { strong alcohol + roots of Caesalpinia } \\
\text { bonduc (L.) Roxb. }\end{array}$ & Drink 3 small glasses/day for $45-60$ days & 1 \\
\hline Stomach pain & $\begin{array}{l}\text { Powder of dried roots }+ \text { water or } \\
\text { alcohol or crushed fresh roots }+ \\
\text { alcohol }\end{array}$ & $\begin{array}{l}\text { Drink } 3 \text { small glasses/day morning, afternoon, } \\
\text { and evening until well }\end{array}$ & 1 \\
\hline Swellings & Crush fresh root & $\begin{array}{l}\text { Apply the paste to the swelling morning and } \\
\text { evening until well }\end{array}$ & 1 \\
\hline Tooth decay & $\begin{array}{l}\text { Wash, scratch the root and cut it in } \\
\text { small pieces }\end{array}$ & $\begin{array}{l}\text { Put a piece on the decayed tooth in the evening } \\
\text { at bedtime until well }\end{array}$ & 0.90 \\
\hline Otitis & $\begin{array}{l}\text { Crush fresh root and press out the } \\
\text { juice }\end{array}$ & $\begin{array}{l}\text { Put some drops in ears morning, afternoon, and } \\
\text { evening until well }\end{array}$ & 0.88 \\
\hline $\begin{array}{l}\text { Headaches } \\
\text { and migraine }\end{array}$ & $\begin{array}{l}\text { Crush fresh root and press out the } \\
\text { juice }\end{array}$ & $\begin{array}{l}\text { Put some drops in the eyes and massage the } \\
\text { forehead with it in case of attack }\end{array}$ & 0.80 \\
\hline Dysmenorrhea & $\begin{array}{l}\text { Cut root in small pieces }+ \text { white } \\
\text { onion }+ \text { seed of } X \text {. aethiopica }+ \text { cola } \\
\text { nut }+ \text { alcohol or water }\end{array}$ & $\begin{array}{l}\text { Drink } 3 \text { small glasses/day in the morning, } \\
\text { afternoon, and evening for } 45-60 \text { days }\end{array}$ & 0.6 \\
\hline Flu and sinusitis & Scrape root and put in a handkerchief & Inhale the smell in case of attack & 0.54 \\
\hline \multirow[t]{3}{*}{$\begin{array}{l}\text { Sexual } \\
\text { weakness } \\
\end{array}$} & $\begin{array}{l}\text { Root }+ \text { hot pepper (crushed whole) }+ \\
\text { strong alcohol + roots of } C . \text { bonduc }\end{array}$ & Drink regularly at will & 0.17 \\
\hline & $\begin{array}{l}\text { Root }+ \text { young leaves of Coldenia } \\
\text { procumbens L. (crushed whole) + } \\
\text { some slightly acidic water ("guissin") } \\
\text { and filter }\end{array}$ & Drink 3 small glasses/day at will & 0.17 \\
\hline & $\begin{array}{l}\text { Infusion of root }+ \text { fresh groundnut }+ \\
\text { onion }\end{array}$ & Drink 3 small glasses/day at will & 0.05 \\
\hline Fever & Crushed root + water & Bathe with the potion in case of attack & 0.11 \\
\hline \multicolumn{4}{|l|}{ Bark } \\
\hline \multirow[t]{2}{*}{ Icterus } & $\begin{array}{l}\text { Infusion of bark }+ \text { root }+ \text { leaf }+ \\
\text { citronella }\end{array}$ & Drink regularly for $10-15$ days & 0.68 \\
\hline & Cut bark as chew stick & $\begin{array}{l}\text { Chew on chew stick and swallow the juice for } \\
10-15 \text { days }\end{array}$ & 0.16 \\
\hline Tooth decay & Cut bark as chew stick & $\begin{array}{l}\text { Chew on chew stick and hold the juice for some } \\
\text { time in the mouth morning and evening until well }\end{array}$ & 0.39 \\
\hline Fever & Soak bark in water & Use water for bath for $3-5$ days & 0.15 \\
\hline \multirow[t]{2}{*}{ Stomach pains } & Cut bark as chew stick & Chew on chew stick and swallow the juice at will & 0.18 \\
\hline & $\begin{array}{l}\text { Infusion of bark + root of Uvaria } \\
\text { chamae P.Beauv. }\end{array}$ & Drink at will & 0.03 \\
\hline Malaria & $\begin{array}{l}\text { Soak bark, collect the mousse, and } \\
\text { add sugar }\end{array}$ & Drink 2 small glasses/day for $5-7$ days & 0.15 \\
\hline
\end{tabular}




\begin{tabular}{|l|l|l|r|}
\hline \multicolumn{3}{|l|}{ Parts used } \\
\hline $\begin{array}{l}\text { IIInesses } \\
\text { treated }\end{array}$ & Recipes & Guidelines for use & CMU \\
\hline Indigestion & Cut bark as chew stick & $\begin{array}{l}\text { Chew on chew stick and swallow the juice } \\
\text { morning, afternoon, and evening until well }\end{array}$ & 0.11 \\
\hline Pods & $\begin{array}{l}\text { Dry carefully washed pods without } \\
\text { seed and soak it in water }\end{array}$ & $\begin{array}{l}\text { Drink 3 glasses/day morning, afternoon, and } \\
\text { evening 5-7 days }\end{array}$ & 0.11 \\
\hline Malaria & Soak pod in water & Bathe with it for 3-5 days & 0.01 \\
\hline Fever & Remove the winged shell of the seed & Eat 2 kernels a day regularly & 0.6 \\
\hline Seeds & Remove the winged shell of the seed & $\begin{array}{l}\text { Eat 2 kernels in the morning, afternoon, and } \\
\text { evening at will }\end{array}$ & 0.41 \\
\hline Diabetes &
\end{tabular}

sheep, while powder is put in water for poultry. According to $49 \%$ of the population surveyed this mode of nutrition favors good growth of these animals, eases births, and improves the litter. Regularly drinking water with the powder of $M$. oleifera leaves protects poultry from diseases and favors bigger and more numerous eggs. In addition to these uses, the seeds of moringa are used to carry out rites for certain purposes, either to attract the opposite sex or clients, to protect oneself against witchcraft, or even to utter blessings on persons.

\section{Discussion}

Most of the local naming hints at the ancient use of the plant for the demarcation of fields and houses; they are thus generic names. None of the local naming is based on the food and medicinal uses, suggesting that these uses are relatively recent in the rural communities of the South Benin.

The use of $M$. oleifera products in traditional medicine and in human and animal nutrition is confirmed by most of the authors on the subject. The nutritional properties of leaves and seeds of $M$. oleifera were shown by Sreelatha and Padma (2009) and Afuang et al. (2003). Thirty-four diseases are treated with various products of $M$. oleifera, as shown by the works of several authors who provide a scientific basis of these uses (Anwar et al. 2006, Anwar et al. 2007, Ayanbimpe et al. 2009, Beltrán-Heredia et al. 2009, Gilani et al. 1994, Kalogo et al. 2000, Kumar et al. 2007, Lea 2010). The massive use of leaves in human and animal nutrition and in traditional medicine implies premature and continuing harvests, which constitutes a pressure on the foliar biomass and consequently on the species. As a result, the populations are not given enough time to flower and thus they fail to produce seeds. It was noticed that the efficacy of remedies quoted by the populations is not always relevant because of weak consensus values $(<0.25)$ in some cases. However a weak consensus value is not always synonymous with ineffectiveness of the remedy, because, for some diseases, only traditional practitioners have the proper knowledge of remedies and don't want to share their knowledge. This may explain the low consensus values of these recipes.

Our results did not reveal a developed trade with $M$. oleifera's products. This is due to the fact that the cultivation of $M$. oleifera is not carried out on a large scale and the fresh leaves are largely consumed as vegetable-leaves. This business is thus little developed compared to that in Niger and Nigeria where leaves of $M$. oleifera are the subject of international trade, mostly during Muslim fasting periods. In fact, in 2010 the Cooperative League of the United States of America, which provides technical assistance to the production of $M$. oleifera in Niger, estimated that Niger imports up to 10,000 tons of dried leaves annually from Nigeria, although Nigeria also experiences high demand during the Muslim fasting period (Kimba et al. 2010). This constitutes a loss of income for Benin which, due to its geographical position, should be the main supplier of these nearby countries with high populations of Muslims.

\section{Conclusion}

Moringa oleifera is a botanical species well-known in Benin in the Guineo-Congolese area and appreciated for its leaves, roots, pods, seeds, and bark. The leaves are used by various ethnic groups as a source of food (vegetableleaves). They are consumed fresh or reduced to powder. The various organs of the plant are used to help in the cure of various diseases such as venereal diseases, cardiovascular diseases, infectious diseases, tropical diseases, inflammatory complaints, oto-rhino-laryngologocal complaints, skin infections, digestive diseases, infertility disorders, etc. All the organs of the species are used to various degrees, and the leaf is the most used organ. The leaves are also used as fodder, and they are included in compounds used in animal production to increase the production. 


\section{Agoyi et al. - Ethnobotanical Assessment of Moringa oleifera Lam. in Southern Benin (West Africa)}

\section{Acknowledgments}

Our acknowledgment goes to the local authorities and local populations which facilitated and helped us in data collection. Our acknowledgment goes also to Prof. Dr. Ir. Romain Glélé Kakai and Prof. Dr. Brice Tente who read and provided us with useful comments to improve the scientific quality of this document. Our acknowledgment goes also to Sally Chikuta and Albert Tsindi for their proofreading.

\section{Literature Cited}

Afuang, W., P. Siddhuraju, \& K. Becker. 2003. Comparative nutritional evaluation of raw, methanol extracted residues and methanol extracts of moringa (Moringa oleifera Lam.) leaves on growth performance and feed utilization in Nile tilapia (Oreochromis niloticus L.). Aquaculture Research 34(13):1147-1159. dx.doi.org/10.1046/j.13652109.2003.00920.x

Agbahungba, G. \& D. Depommier. 1989. Aspects du parc à Karités-Nérés (Vitellaria paradoxa Gaertn.f., Parkia biglobosa jacq. Benth.) dans le sud du Borgou (Bénin). Bois et Forêts des Tropiques 222:41-54.

Anwar, F., S. Latif, M. Ashraf \& A.H. Gilani. 2006. Moringa oleifera: A food plant with multiple medicinal uses. Phytotherapy Research 21(1):17-25. dx.doi.org/10.1002/ ptr.2023

Anwar, F., A. Siddiq, S. Iqbal \& M.R. Asi. 2007. Stabilization of sunflower oil with Moringa oleifera leaves under ambient storage. Journal of Food Lipids 14(1):35-49. dx.doi.org/10.1111/j.1745-4522.2006.00069.x

Assogbadjo, A.E., G. Amadji, R. Glèlè Kakaı, A. Mama, B. Sinsin \& P. Van Damme. 2009. Evaluation écologique et ethnobotanique de Jatropha curcas L. au Bénin. International Journal of the Biological and Chemical Sciences 3(5):1065-1077. dx.doi.org/10.4314/ijbcs.v3i5.51085

Assogbadjo, A.E., E. De Caluwe, B. Sinsin, J.T.C. Codjia \& P. Van Damme. 2005a. Indigenous knowledge of rural people and importance of baobab tree (Adansonia digitata L.) in Benin. Pp. 39-47 in Proceedings of the Fourth International Congress of Ethnobotany (ICEB 2005). Ethnobotany: At the junction of the continents and the disciplines. 21-26 August 2005, Istanbul, Turkey.

Assogbadjo, A.E., R. Glèlè Kakaï, F.J. Chadare, L. Thomson, T. Kyndt \& B. Sinsin. 2008. Folk classification, perception and preferences of baobab products in West Africa: Consequences for species conservation and improvement. Economic Botany 62(1):74-84. dx.doi/org/10.1007/ $\underline{\text { s12231-007-9003-6 }}$

Assogbadjo, A.E., R. Glèlè Kakaï, F.G. Vodouhê, C.A.M.S. Djagoun, J.T.C. Codjia \& B. Sinsin. 2012. Biodiversity and socioeconomic factors supporting farmers' choice of wild edible trees in the agroforestry systems of Benin (West Africa). Forest Policy and Economics 14(1):41-49. dx.doi. org/10.1016/j.forpol.2011.07.013

Assogbadjo, A.E., T. Kyndt, B. Sinsin, G. Gheysen \& P. Van Damme. 2006. Patterns of genetic and morphometric diversity in baobab (Adansonia digitata L.) populations across different climatic zones of Benin (West Africa). Annals of Botany (London) 97(5):819-830. dx.doi. org/10.1093/aob/mcl043

Assogbadjo, A.E., B. Sinsin, J.T.C. Codjia \& P. Van Damme. 2005b. Ecological diversity and pulp, seed and kernel production of the baobab (Adansonia digitata) in Benin. Belgian Journal of Botany 138(1):47-56.

Assogbadjo, A.E., B. Sinsin, P. Van Damme. 2005c. Caractères morphologiques et production des capsules de baobab (Adansonia digitata L.) au Bénin. Fruits 60(5):327340. dx.doi.org/10.1051/fruits:2005039

Aubé, J. 1996. Etude pour favoriser le développement des produits forestiers non ligneux dans le cadre du "Central African Regional Programme for the Environment." CARPE 154:5-7.

Ayanbimpe, G.M., T.K. Ojo, E. Afolabi, F. Opara, S. Orsaah \& O.S. Ojerinde. 2009. Evaluation of extracts of Jatropha curcas and Moringa oleifera in culture media for selective inhibition of saprophytic fungal contaminants. Journal of Clinical Laboratory Analysis 23(3):161-164. dx.doi. org/10.1002/jcla.20311

Beltrán-Heredia, J., J. Sánchez-Martïn \& A. DelgadoRegalado. 2009. Removal of dyes by Moringa oleifera seed extract. Study through response surface methodology. Journal of Chemical Technology and Biotechnology 84(11):1653-1659. dx.doi.org/10.1002/jctb.2225

Byg, A. \& H. Balslev. 2001. Diversity and use of palms in Zahamena, eastern Madagascar. Biodiversity and Conservation 10(6):951-970. dx.doi. org/10.1023/A:1016640713643

Codjia, J.T.C. \& A.E. Assogbadjo. 2001. Report on the Workshop "Diversité des Ressources Forestières Alimentaires du Bénin, Rôle Pour les Populations et Possibilité de Valorisation pour un Développement Humain Durable." 25-29 Juin 2001. Aménagement Intégré des Forêts Naturels des Zones Tropicales Sèches en Afrique de l'Ouest, Parakou, Bénin.

Codjia, J.T.C., A.E. Assogbadjo \& M.R.M. Ekue. 2003. Diversite' et valorisation au niveau local des ressources forestières alimentaires végétales du Bénin. Cahiers Agricultures 12:321-331. 
Dagnelie, P. 1998. Statistique Théorique et Appliquée. Tome 2: Inférence statistique à une et à deux dimensions. De Boeck et Larcier, Paris, France, et Bruxelles, Belgique.

Dethier, M. 1998. Valorisation des Produits Forestiers non Ligneux de la Forêt Dense Humide Tropicale: Application à la gestion durable de la forêt communautaire de Kompia (Est Cameroun). Mémoire de fin d'études (ingénieur). Faculté Universitaire des Sciences Agronomiques, Gembloux, Belgique.

Floquet, A. \& E. Van der Akker. 2000. Ethnic groups and settlement patterns in Benin. Pp. 255-258 in Adapted Farming in West Africa: Issues, potentials and perspectives. Edited by F. Graef, P. Lawrence \& M. von Oppen. Verlag Ulirich E. Grauer, Stuttgart, Germany.

Gilani, A.H., K. Aftab, A. Suria, S. Siddiqui, R. Salem, B.S. Siddiqui \& S. Faizi. 1994. Pharmacological studies on hypotensive and spasmolytic activities of pure compounds from Moringa oleifera. Phytotherapy Research 8(2):8791. dx.doi.org/10.1002/ptr.2650080207

Kalogo, Y., F. Rosillon, F. Hammes \& W. Verstraete. 2000. Effect of a water extract of Moringa oleifera seeds on the hydrolytic microbial species diversity of a UASB reactor treating domestic wastewater. Letters in Applied Microbiology 31(3):259-264. dx.doi.org/10.1046/j.1365$\underline{2672.2000 .00814 . x}$

Kimba, A., B. Dan Marafa \& A. Hima. 2010. Le moringa, une demande forte, une offre insuffisante. Bulletin RECA INFO 9:1-3.

Kouyaté, A.M. 2005. Aspects Ethnobotaniques et Etude de la Variabilité Morphologique, Biochimique et Phénologique de Detarium microcarpum Guill. \& Perr. Thèse de doctorat, University of Mali, Faculty of Biosciences Ingenious, Bamako, Mali.

Kumar, S., D. Kumar, N. Singh \& B.D. Vashishta. 2007. In vitro free radicals scavenging and antioxidant activity of Moringa oleifera pods. Journal of Herbal Medicine and Toxicology 1:17-22.

Lea, M. 2010. Bioremediation of turbid surface water using seed extract from Moringa oleifera Lam. (drumstick tree). Current Protocols in Microbiology 16:1G.2.11G.2.8. dx.doi.org/10.1002/9780471729259.mc01g02s33

Leonard, M. \& P. Rweyemamu. 2006. Report on Workshop "Moringa et Autres Végétaux à Fort Potentiel Nutritionnel: Stratégies, normes et marchés pour un meilleur impact sur la nutrition en Afrique." 16-18 Novembre 2006, Accra, Ghana.

Oliveira, J.T., S.B. Silveira, I.M. Vasconcelos, B.S. Cavada \& R.A. Moreira. 1999. Compositional and nutritional attributes of seeds from the multiple purpose tree Moringa oleifera Lamarck. Journal of the Science of Food and Agriculture 79(6):815-820. dx.doi.org/10.1002/(SICI)10970010(19990501)79:6<815::AID-JSFA290>3.0.CO;2-P

Sreelatha, S. \& P.R. Padma. 2009. Antioxidant activity and total phenolic content of Moringa oleifera leaves in two stages of maturity. Plant Foods for Human Nutrition (Dordrecht, Netherlands) 64:303-311.

Sunderland, T., L. Clark \& P. Vantomme. 2000. Les Produits Forestiers non Ligneux en Afrique Centrale: Recherches actuelles et perspectives pour la conservation et le développement. Food and Agricultural Organization of the United Nations, Rome, Italy.

Verdcourt, B. 1985. A synopsis of the Moringaceae. Kew Bulletin 40:1-23.

Yorou, S. \& A. DeKersel. 2000. Diversité et Productivité des Champignons Comestibles de la Forêt Classée de Wari-Maro (Bénin). Laboratoire d'Ecologie Appliquée (LEA), Université D’Abomey-Calavi, Bénin et Jardin Botanique National de Belgique, Belgique. 